\title{
Effects of animal manure upon growth of Cerrado plants
}

Through excretion, animals return to the soil part of the nutrients they ingest. This input can be an alternative to artificial inorganic fertilization aiming at increasing soil nutrient concentrations in degraded areas that are prone to restoration. In nutrient-poor soils, the addition of animal manure can promote increases in soil fertility, but studies assessing its effects upon plant communities are meager. This study aims at checking whether the addition of manure originated from livestock promotes plant growth increase and enzyme activity in Cerrado native plants of different functional groups as a way to subsidize processes of environmental recuperation in degraded areas using organic fertilization of an easily available source, as animal manure. The experiment was conducted in a screenhouse through a completely randomized design with four manure and six species treatments with three replicates. Manure treatments used were control, cattle, sheep and goat manure. The plant species selected belonged to main Cerrado herbaceous functional groups - two naturalized grasses, two alien invasive grasses, a legume herb and a Malvaceae herb. Phosphorus and nitrogen concentrations, and N:P ratios varied according to the type of manure. Soil organic matter content, phosphorus and potassium concentrations increased upon manure addition. Different manure types promoted various effects in height, biomass and acid phosphatase activity amongst the plants. Goat and cattle manure positively influenced Urochloa decumbens, an exotic invasive grass living in the Cerrado, whereas sheep manure addition promoted increase of non-invasive grasses. These results show that animal manure can promote better nutrient conditions for plants living in degraded areas, but the selection of the manure type for application in restoration projects aiming at aiding plant growth in Cerrado degraded areas will depend on the purpose of the project because different dung types benefit different plant functional groups.

Keywords: Environmental Restoration; Invasive Species; N:P Ratio; Nutrients; Plant Functional Groups.

\section{Efeitos da adição de esterco animal sobre o crescimento de plantas de Cerrado}

\begin{abstract}
Através da excreção, animais devolvem aos ecossistemas parte dos nutrientes que ingerem. Esta entrada de nutrientes pode atuar como uma alternativa à fertilização inorgânica artificial visando o aumento do teor de nutrientes no solo em áreas degradadas em processo de restauração ambiental. Em solos pobres em nutrientes, a adição de esterco animal pode promover aumentos na fertilidade do solo, mas estudos acessando seus efeitos sobre comunidades vegetais são escassos. Este estudo visa investigar se a adição de esterco oriundo de animais de produção afeta o crescimento e a atividade enzimática de plantas de diferentes grupos funcionais de Cerrado como uma maneira de dar subsídio ao processo de recuperação ambiental em áreas degradadas utilizando fertilização orgânica e facilmente disponível, como esterco. O experimento foi conduzido em casa de vegetação com três tipos de esterco (bovino, ovino e caprino) e um controle, seis espécies de plantas e três réplicas. As espécies de plantas utilizadas pertencem a grupos funcionais comuns no Cerrado - duas espécies de gramíneas naturalizadas, duas espécies de gramíneas invasoras, uma leguminosa e uma Malvaceae. Concentrações de nitrogênio e fósforo e razões N:P variaram de acordo com o tipo de esterco. Conteúdo de matéria orgânica no solo, além das concentrações de fósforo e potássio no solo aumentaram significativamente com a adição de esterco. Os diferentes tipos de esterco promoveram diversos efeitos em altura, biomassa e atividade de fosfatase ácida nas plantas. Estercos bovino e caprino influenciaram positivamente o crescimento da planta exótica invasora Urochloa decumbens, enquanto o esterco ovino promoveu o crescimento de gramíneas não invasoras Estes resultados demonstram que a utilização de esterco animal promove melhores condições nutricionais para plantas que vivem em áreas degradadas, e que a seleção do tipo de esterco a ser utilizado em projetos de recuperação ambiental objetivando incrementar o crescimento vegetal em áreas degradadas dependerá do objetivo da restauração, uma vez que diferentes tipos de esterco favorecem diferentes grupos funcionais de plantas.
\end{abstract}

Palavras-chave: Espécies Invasoras; Grupos Funcionais; Nutrientes; Razão N:P; Recuperação Ambiental.

Topic: Conservação da Biodiversidade

Reviewed anonymously in the process of blind peer.
Received: 03/05/2020

Approved: 04/06/2020
Lucas Ferreira (D)

Universidade Estadual Paulista, Brasil

http://lattes.cnpq.br/1264913582919758

http://orcid.org/0000-0003-4699-3549

eng.agro.lucas@hotmail.com

Mairê Butzer Viñales (iD)

Universidade Estadual Paulista, Brasil

http://lattes.cnpq.br/4445166944442386

http://orcid.org/0000-0002-2982-9264

maire.vinales@unesp.br

Lucas Lopes e Silva (iD)

Universidade Estadual Paulista, Brasil

http://lattes.cnpq.br/1557494898553937

http://orcid.org/0000-0002-3491-2732

lukaslls@hotmail.com
Luciola Santos Lannes (iD

Universidade Estadual Paulista, Brasil

http://lattes.cnpq.br/4457583288339052

http://orcid.org/0000-0002-0603-4071

luciola.lannes@unesp.br
Referencing this:

FERREIRA, L.; VIÑALES, M. B.; SILVA, L. L.; LANNES, L. S.. Effects of animal manure upon growth of Cerrado plants. Revista IberoAmericana de Ciências Ambientais, v.11, n.4, p.81-88, 2020. DOI: http://doi.org/10.6008/CBPC2179-6858.2020.004.0007 


\section{INTRODUCTION}

The diversity in plant communities is influenced by several processes, and nutrient availability is one of its main determinants (GRACE et al., 2016). Researches developed in the African savanna help us to understand the role of animal grazing and browsing upon the nutrition of local plant communities (DE IONGH et al., 2011; SITTERS et al., 2014; SITTERS et al., 2018). Herbivores can keep an equilibrium between nutrients they ingest and release through manure deposition, maintaining soil fertility and avoiding that the final balance is negative for the ecosystem (VAN DER WAAL et al., 2011).

It is known that herbivores living in African savannas have different manure qualities, varying in nitrogen $(N)$, phosphorus $(P)$ and N:P stoichiometry (N:P ratios) (SITTERS et al., 2014). The effect of these different nutrient conditions upon plant communities deserve investigation because they can imply in specific responses of the vegetation since plants from different functional groups can compete differently for different soil nutrients (VENTERINK et al., 2010; FUJITA et al., 2014). Therefore, differences in the plant community composition can exist when $\mathrm{N}$ or $\mathrm{P}$ are the main limiting nutrients (VENTERINK, 2011a). Colimitation between $N$ and $P$ and other nutrients are also found in plant communities, when these synergistically pose an effect of plant growth (HARPOLE et al., 2011).

For Brazilian animals and plant communities there is a knowledge gap concerning the effect of manure additions and of their diversified nutrient contents on plant growth. The Brazilian Cerrado is a biodiversity hotspot (MYERS et al., 2000) undergoing several threats due to agricultural and industrial expansion and in need of development of techniques aiding the recuperation of the degraded areas in this biome (ALVES et al., 2012). Recently, Teixeira et al. (2019) showed that the addition of sheep manure in a degraded area in the Cerrado promoted soil nutrient enrichment and further helped plant establishment, suggesting that this practice can be successfully applied as a natural organic source of nutrients to the soil.

Cattle, goat and sheep excrete most of the nutrients they ingest. Their manures are rich in organic matter and mineral nutrients, and their additions as fertilizers promoted productivity increases in pepper (Capsicum annuum) in Nigeria (AWODUN et al., 2007) and in cactus (Nopalea cochenillifera Salm Dyck) in Brazil (MIRANDA et al., 2019).

In this research we hypothesize that the addition of cattle, goat and sheep manure will influence differently growth of Cerrado functional groups since those manure types have different nutrient concentrations and N:P ratios, and different functional groups are limited by different nutrients in the Cerrado (LANNES et al., 2016). Understanding how the addition of manure originating from different livestock grown in the Cerrado as a nutrient source to Cerrado plants will be useful in projects of land recuperation, restoration and conservation in this important Brazilian biome.

\section{MATERIALS AND METHODS}

The experiment was conducted in a screenhouse at UNESP in Ilha Solteira, SP, Brazil. We used a completely randomized design using a factorial scheme of $4 \times 7$, with 3 replicates per treatment, with a total 
of 72 pots. The first factor was manure type (4 levels - control, cattle, sheep and goat), and the second factor applied was species type, composed by 7 levels - without plants, two naturalized grasses (Digitaria insularis and Melinis repens), two invasive grasses (Urochloa decumbens and Melinis minutiflora), a legume herb (Calopogonium mucunoides) and a Malvaceae (Sida cerradoensis).

In August 2018, seeds of these species were germinated in a screenhouse in trays containing Cerrado soil collected in a degraded area nearby the dam of Ilha Solteira, SP, Brazil. In September three individuals of each species were transplanted to 1-liter pots containing substrate composed by one part of washed quartz sand to one part of the above-mentioned soil.

Sheep, goat and cattle manure were collected in September 2018 at UNESP Animal Science farm, dried at $60 \stackrel{\circ}{\circ}$, ground and sent to the Laboratory of Plant Ecology of UNESP Ilha Solteira to have their chemical characteristics determined according to Malavolta et al. (1997). After plant establishment in the pots, 50 grams of each manure type was applied to the pots, and the experiment ran for two months. During harvest, plant height was measured. A sample of $100 \mathrm{mg}$ of roots was collected for immediate determination of phosphomonoesterase activity according to the nitrophenil-phosphate method (VENTERINK, 2011b). Plant material was rinsed and dried at $70^{\circ} \mathrm{C}$ during 72 hours, and weighed.

Soil chemical characteristics were determined in air-dried samples according to Raij et al. (2001), i.e., through resin- $\mathrm{P},-\mathrm{K},-\mathrm{Ca}$ and $-\mathrm{Mg}$, using DTPA as extractant for $\mathrm{Cu}, \mathrm{Fe}, \mathrm{Mn}$ and $\mathrm{Zn}$, with hot water and barium chloride, before a reaction with azometin, for boron, after titration with phenolphthalein for aluminium and through reaction with calcium phosphate for sulphur. Organic matter was extracted with sodium dichromate and chloridric acid, sulphur was determined after reaction with calcium phosphate and precipitation with barium chloride, and $\mathrm{pH}$ was measured in a water-soil suspension (10 grams air-dry soil $<2 \mathrm{~mm}$ with $50 \mathrm{~mL}$ deionised water). Concentrations in the extracts were determined with a spectrophotometer (Varian 50 Probe) for organic matter, P, S and B, and by atomic absorption (Varian Spectraa, 55B) for K, Ca, Mg, Cu, Fe, $\mathrm{Mn}, \mathrm{Zn}$.

Standardized differences between means of plant biomass, height and acid phosphomonoesterase activity between control and manure-treated plots were calculated as Cohen's $d$ effect size measures (COHEN, 2013). The determination of the treatment effects upon the variables measured was done through ANOVA followed by LSD or Dunnett post-hoc tests, using R version 3.5.2 (R CORE TEAM, 2013). Data were log-transformed if necessary to guarantee normal distribution of residues.

\section{RESULTS}

Manure addition promoted significant increases in soil organic matter content, phosphorus and potassium concentrations (Table 1). Soil calcium, magnesium, manganese, sulfur, boron, aluminium, copper, iron, zinc and $\mathrm{pH}$ were not significantly affected by manure addition. The three different manure types differed significantly in relation to $\mathrm{N}$ and $\mathrm{P}$ concentrations, and to $\mathrm{N}: \mathrm{P}$ ratios (Fig. 1). The highest concentrations of $\mathrm{N}$ and $\mathrm{P}$ were detected in goat manure, followed by sheep manure, and then by cattle manure. Sheep manure had the highest N:P ratios, followed by cattle and then by goat manure. 
Table 1: Soil characteristics of control plots (without plants) with different manure treatments. Asterisks represent means differences between the dung type and the 'No addition' treatment (ANOVA+Dunnett, $P<0.05, N=3$ ).

\begin{tabular}{|l|l|l|l|l|}
\hline Soil attribute & No addition & Cow & Goat & Sheep \\
\hline Organic matter $\left(\mathrm{g} \mathrm{kg}^{-1}\right)$ & $16.1(1.8)$ & $24.8(3.2)^{*}$ & $23.1(4.6)^{*}$ & $28.7(3.0)^{*}$ \\
\hline Phosphorus $\left(\mathrm{mg} \mathrm{kg}^{-1}\right)$ & $1.5(0.3)$ & $2.6(0.2)^{*}$ & $4.3(1.3)^{*}$ & $2.8(0.6)^{*}$ \\
\hline Potassium $\left(\mathrm{mg} \mathrm{kg}^{-1}\right)$ & $22.5(8.0)$ & $45.6(1.7)^{*}$ & $48.9(7.5)^{*}$ & $39.1(6.6)^{*}$ \\
\hline Calcium $\left(\mathrm{mg} \mathrm{kg}^{-1}\right)$ & $102(21.0)$ & $113(14.0)$ & $108(54.0)$ & $105(10.0)$ \\
\hline Magnesium $\left(\mathrm{mg} \mathrm{kg}^{-1}\right)$ & $29(3.0)$ & $31(14.0)$ & $30(5.0)$ & $23(8.0)$ \\
\hline Manganese $\left(\mathrm{mg} \mathrm{kg}^{-1}\right)$ & $4.8(2.1)$ & $5.3(1.6)$ & $5.3(2.0)$ & $5.7(1.0)$ \\
\hline Sulfur $\left(\mathrm{mg} \mathrm{kg}^{-1}\right)$ & $21.4(6.3)$ & $26.5(1.9)$ & $22.6(4.3)$ & $20.0(8.5)$ \\
\hline Boron $\left(\mathrm{mg} \mathrm{kg}^{-1}\right)$ & $0.04(0.01)$ & $0.04(0.01)$ & $0.05(0.02)$ & $0.04(0.02)$ \\
\hline Aluminium (mg kg-1) & $23(3.0)$ & $22(6.0)$ & $23(5.0)$ \\
\hline Copper $\left(\mathrm{mg} \mathrm{kg}^{-1}\right)$ & $9(4.0)$ & $10(2.0)$ & $10(4.0)$ & $9(6.0)$ \\
\hline Iron $\left(\mathrm{mg} \mathrm{kg}^{-1}\right)$ & $4.6(1.4)$ & $4.8(0.6)$ & $4.6(1.2)$ & $4.3(1.8)$ \\
\hline Zinc $\left(\mathrm{mg} \mathrm{kg}^{-1}\right)$ & $0.08(0.01)$ & $0.09(0.02)$ & $0.10(0.04)$ & $0.07(0.03)$ \\
\hline $\mathrm{pH}$ & $4.3(1.2)$ & $4.2(1.0)$ & $4.3(1.1)$ & $4.4(0.6)$ \\
\hline
\end{tabular}

The functional groups responded differently in terms of biomass to the manure additions (Fig. 2). The Malvaceae Sida cerradoensis responded negatively to the addition of all types of manure, and significantly to the sheep manure. The legume Calopogonium mucunoides did not respond significantly to the manure additions, but showed different responses according to the manure type, with the goat manure promoting a negative effect upon its growth. The grass Digitaria insularis responded positively and significantly to the treatment with sheep and cattle manure, but responded negatively to the goat addition, though not significantly. The grasses Urochloa decumbens, Melinis minutiflora and Melinis repens responded generally positively to the addition of all kinds of manure.

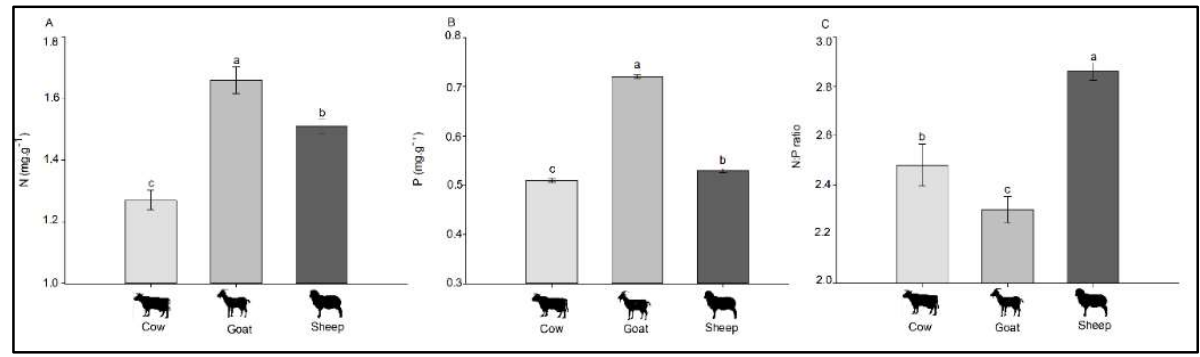

Figure 1: Nitrogen $(N)$ and phosphorus $(P)$ concentrations and $N: P$ ratios in the manure of the ruminants used in this study. Values shown correspond to means followed by standard deviations. Values in $\mathrm{mg} \cdot \mathrm{g}^{-1}$. Different letters indicate significant statistical differences at $\mathrm{P}(\mathrm{ANOVA}+\mathrm{LSD})<0.01 . \mathrm{N}=3$.

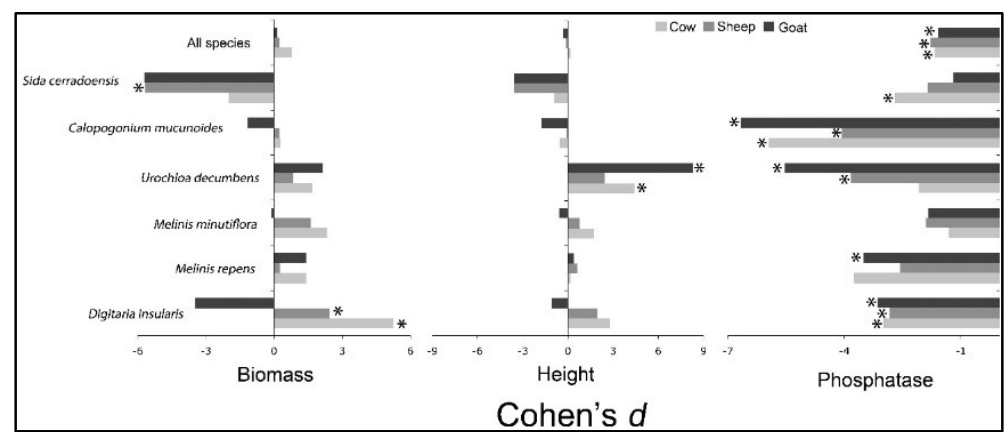

Figure 2: Effect sizes of manure addition on biomass, height and acid phosphatase activity of six Cerrado herbaceous species. Positive values show that the manure addition promoted increase in the respective variable in relation to the control pots. Asterisks indicate significant differences (ANOVA+LSD, $P<0.05$ ), $N=3$.

The response also varied with species in relation to the effect of manure addition on plant height. The exotic invasive grass Urochloa decumbens responded strongly (Cohen's distance > $|0.8|$ ) and significantly to goat and cattle manure additions, whereas the other grasses responded discreetly. Height of non- 
graminoids had generally negative responses to manure additions, similarly to the biomass. The activity of acid phosphatase strongly decreased in all species following manure addition (Fig. 2), significantly in most cases.

\section{DISCUSSION}

This study shows that plants belonging to different functional groups in the Cerrado respond differently to manure types of livestock in Brazil. In general, the studied plants responded better to the addition of sheep and cattle manure than to the addition of goat manure. For the naturalized grass Digitaria insularis, the addition of cattle and sheep manure promoted significant increases in biomass, oppositely to the addition of goat manure. We cannot, however, generalize this effect since another naturalized grass, Melinis repens, did not respond significantly to manure addition. It is already known that native plant communities can be limited by one or more nutrients, especially by $\mathrm{N}$ and $\mathrm{P}$ when added in their inorganic form (DAVIDSON et al., 2007; ELSER et al., 2007; HARPOLE et al., 2011; FAY et al., 2015). Considering that the different kinds of manure used in this experiment presented different $\mathrm{N}$ and $\mathrm{P}$ contents, it can be seen that plants also responded to nutrient addition when they are added organically to the soil. Other studies, in natural savanna environments, showed this plant response to different manure types. Sitters et al. (2014) reported a large variation in $\mathrm{N}$ and $\mathrm{P}$ contents amongst the animals they studied in an African savanna, promoting different effect upon vegetation, being related to different feeding strategies (grazers vs. browsers) and digestive physiology (ruminants vs non-ruminants). Even though we only used manure of ruminants in this study, there were strong differences in nutrient concentrations and they promoted varied responses in the several plants studied.

The enzyme phosphatase is associated to the $\mathrm{P}$ cycle and its function is to extract phosphate groups from organic-P fractions under P deficiency (VENTERINK et al., 2010). In the extremely P-poor Cerrado soils, plants clearly benefit from the activity of the enzyme phosphatase by acquiring phosphorus made available (GOEDERT, 1983). In this research, however, the addition of all manure types promoted decreases in phosphatase activity, showing that manure addition alleviated P-limitation. Although most of the nutrients are in the organic form in the manure, these are easily decomposable into inorganic forms without the needing enzyme participation in the process. This is as a positive effect of manure addition upon the physiology of the studied plants since the production of this enzyme is energetically highly costly for the plant.

For the exotic invasive grass Urochloa decumbens, the addition of goat and cattle manure caused a significant increase in height in relation to the controls. Teixeira et al. (2019), when evaluating the effect of sheep manure on plant production in a Cerrado degraded area 21 months after fertilization, found that this organic source of nutrients tripled the growth of Urochloa decumbens in relation to the unfertilized control plots. These authors stated that the addition of sheep manure promoted changes in soil physical and chemical attributes and stimulated growth of plant functional groups in their studied area, but with no changes in the biomass of naturalized grasses or legume herbs, what is in agreement of the results of the 
present study. We note that the experiment performed by Teixeira et al. (2019) was conducted in plots containing natural community assemblages containing several species, therefore the effect observed specifically on Urochloa decumbens might be due to its competitive superiority in a nutrient-rich environment since this exotic invasive plant has faster growth than native plants under such conditions (ELLER et al., 2017).

In this experiment, the species were cultivated in monocultures and Urochloa decumbens responded better to the addition of goat and cattle manure, which can be explained by the type of nutritional strategy used by this species. It responds positively to the addition of nitrogen and phosphorus (HEINRICHS et al., 2013; MACHADO et al., 2017; AVELINO et al., 2019), and is limited by mineral phosphorus in the Brazilian Cerrado (LANNES et al., 2016). Nitrogen enrichment often results in a higher phosphorus absorption because it stimulates plant strategies for phosphorus acquisition, as release of enzymes (e.g. phosphatases), symbiotical associations and activity of microorganisms (TEUTSCHEROVA et al., 2019). The goat manure is, amongst the ones applied in this experiment, the one presenting the highest $\mathrm{N}$ and $\mathrm{P}$ contents, therefore favoring those exotic invasive plants.

According to recent findings, the N:P stoichiometry in manure influencing plant responses can be as important as the absolute concentrations of the single nutrients in the manure (VALDÉS-CORRECHER et al., 2019), potentially controlling plant invasion (GONZÁLEZ et al., 2010). As Lannes et al. (2012) reported, invasive plants in the Cerrado, including Urochloa decumbens, have a better development in areas with low vegetation $\mathrm{N}: \mathrm{P}$ ratios, as is the goat manure employed in this study. However, this is the first time that a response of this invasive plant is detected to an organic fertilizer of low N:P ratio, showing that not only mineral fertilization can enhance growth of alien native plants (as seen in LANNES et al., 2016), but organic fertilization with goat manure can also contribute to its maintenance in the $\mathrm{N}$-limitation range.

The fact that the goat manure promoted growth of Urochloa decumbens leads to a paradox in relation to the use this type of manure in restoration areas. On one side, Urochloa decumbens has been widely and successfully used to promote amelioration of soil physical and chemical attributes in degraded areas in the Brazilian Cerrado (CARVALHO et al., 2015). On the other side, the development of this plant in Cerrado areas is not ecologically desirable, since it can dominate large patches of the environment, threaten native plants and jeopardize local biodiversity (PIVELLO et al., 1999), possibly causing loss of threatened species (LANNES et al., 2012). As this study revealed that another grass, Digitaria insularis, responded well to sheep manure in terms of biomass, we recommend further studies focusing on the potential of this species growing under sheep manure fertilization as a possible solution for recuperation of highly degraded areas as an alternative to the employment of Urochloa decumbens for such function.

This work is the first to demonstrate, through an experimental approach, that manure from different livestock in Brazil can have effects on growth of plants that can be used for recuperation of degraded areas. Since Brazil is one of largest animal producing countries in the world and the Brazilian Cerrado has extensive degraded areas, this work contributes to environmental conservation and restoration based on a sustainable approach. 


\section{CONCLUSIONS}

The addition of cattle, goat and sheep manure affected growth of different functional groups of Cerrado plants. This was due to the nutritional requirements of the plants studied and to the nutrient content and stoichiometric differences amongst the manure types used. We recommend the use of the grass Digitaria insularis under sheep manure addition as a potential solution for the initial stages of succession after disturbance as an alternative to the employment of the highly invasive grass Urochloa decumbens for recuperation of degraded areas in the Cerrado.

ACKNOWLEDGMENTS: The authors would like to thank the staff from the UNESP Farm in Ilha Solteira for providing the manure for the experiment.

\section{REFERENCES}

ALVES, M. C.; NASCIMENTO, V.; SOUZA, Z. M.. Recuperação em área de empréstimo usada para construção de usina hidrelétrica. Revista Brasileira de Engenharia Agrícola e Ambiental, v.16, n.8, p.887-893, 2012. DOI: http://doi.org/10.1590/S1415-43662012000800011

AVELINO, A. C. D.; FARIA, D. A.; PENSO, S.; LIMA, D. O. S.; RODRIGUES, R. C.; ABREU, J. G.; PEIXOTO, W. M.. Agronomic and Bromatological Traits of Brachiaria brizantha cv. Piatã as Affected by Nitrogen Rates and Cutting Heights. Journal of Experimental Agriculture International, v.36, n.6, p.1-11, 2019. DOI: http://doi.org/10.9734/jeai/2019/v36i630253

AWODUN, M. A.; OMONIJO, L. I.; OJENIYI, S. O.. Effect of goat dung and NPK fertilizer on soil and leaf nutrient content, growth and yield of pepper. International Journal of Soil Science, v.2, n.2, p.142-147, 2007. DOI: http://doi.org/10.3923/ijss.2007.142.147

CARVALHO, J. C. B.; ESPINDOLA, C. R.; ALVES, M. C.; FIGUEIREDO, G. C.; DECHEN, S. C. F.. Recovery of an oxisol degraded by the construction of a hydroelectric power plant. Revista Brasileira de Ciência Do Solo, v.39, n.6, p.17761785, 2015. DOI: http://doi.org/10.1590/01000683rbcs20140641

COHEN, J.. Statistical power analysis for the behavioral sciences. 2 ed. New York: Routledge, 2013.

DAVIDSON, E. A.; HOWARTH, R. W.. Environmental science: nutrients in synergy. Nature, v.449, p.1000-1001, 2007. DOI: http://doi.org/10.1038/4491000a

ELLER, C. B.; OLIVEIRA, R. S.. Effects of nitrogen availability on the competitive interactions between an invasive and a native grass from Brazilian cerrado. Plant and Soil, n.410, p.63-72, 2017. DOI: http://doi.org/10.1007/s11104-016$\underline{2984-0}$

ELSER, J. J.; BRACKEN, M. E. S.; CLELAND, E. E.; GRUNER, D. S.; HARPOLE, W. S.; HILLEBRAND, H.; NGAI, J. T.; SEABLOOM, E. W.; SHURIN, J. B.; SMITH, J. E.. Global analysis of nitrogen and phosphorus limitation of primary producers in freshwater, marine and terrestrial ecosystems. Ecology Letters, v.10, n.12, p.1135-1142, 2007. DOI:

\section{http://doi.org/10.1111/j.1461-0248.2007.01113.x}

FAY, P. A.; et al.. Grassland productivity limited by multiple nutrients. Nature Plants, v.1, n.7, p.15080, 2015. DOI: http://doi.org/10.1038/nplants.2015.80

FUJITA, Y.; VENTERINK, H. O.; VAN BODEGOM, P. M.; DOUMA, J. C.; HEIL, G. W.; HÖLZEL, N.; JABLONSKA, E.; KOTOWSKI, W.; OKRUSZKO, T.; PAWLIKOWSKI, P.; DE RUITER, P. C.; WASSEN, M. J.. Low investment in sexual reproduction threatens plants adapted to phosphorus limitation. Nature, v.505, p.82-86, 2014. DOI: http://doi.org/10.1038/nature12733

GOEDERT, W. J.. Management of the Cerrado soils of Brazil: a review. Journal of Soil Science, v.34, n.3, p.405-428, 1983. DOI: http://doi.org/10.1111/j.1365-2389.1983.tb01045.x

GONZÁLEZ, A. L.; KOMINOSKI, J. S.; DANGER, M.; ISHIDA, S.; IWAI, N.; RUBACH, A.. Can ecological stoichiometry help explain patterns of biological invasions?. Oikos, v.119, n.5, p.779-790, 2010. DOI: http://doi.org/10.1111/j.16000706.2009.18549.x

GRACE, J. B.; et al.. Integrative modelling reveals mechanisms linking productivity and plant species richness. Nature, v.529, p.390-393, 2016. DOI: http://doi.org/10.1038/nature16524

HARPOLE, W. S.; NGAI, J. T.; CLELAND, E. E.; SEABLOOM, E. W.; BORER, E. T.; BRACKEN, M. E. S.; ELSER, J. E.; GRUNER, D. S.; HILLEBRAND, H.; SHURIN, J. B.; SMITH, J. E.. Nutrient colimitation of primary producer communities. Ecology Letters, v.14, n.9, p.852-862, 2011. DOI: http://doi.org/10.1111/j.1461-0248.2011.01651.x

HEINRICHS, R.; GRANO, F. G.; BUENO, L. G. F.; SOARES FILHO, C. V.; FAGUNDES, J. L.; REBONATTI, M. D.; OLIVEIRA, K.. Brachiaria sp yield and nutrient contents after nitrogen and sulphur fertilization. Revista Brasileira de Ciência do Solo, v.37, n.4, p.997-1003, 2013. DOI: http://doi.org/10.1590/S0100-06832013000400017

IONGH, H. H.; DE JONG, C. B.; VAN GOETHEM, J.; KLOP, E.; BRUNSTING, A. M. H.; LOTH, P. E.; PRINS, H. H. T.. Resource 
partitioning among African savanna herbivores in North Cameroon: the importance of diet composition, food quality and body mass. Journal of Tropical Ecology, n.27, v.5, p.503513, 2011. DOI:

\section{http://doi.org/10.1017/S0266467411000307}

LANNES, L. S.; BUSTAMANTE, M. M. C.; EDWARDS, P. J.; VENTERINK, H. O.. Alien and endangered plants in the Brazilian Cerrado exhibit contrasting relationships with vegetation biomass and $\mathrm{N}$ : P stoichiometry. New Phytologist, v.196, n.3, p.816-823, 2012. DOI: http://doi.org/10.1111/j.1469-8137.2012.04363.x

LANNES, L. S.; BUSTAMANTE, M. M. C.; EDWARDS, P. J.; VENTERINK, H. O.. Native and alien herbaceous plants in the Brazilian Cerrado are (co-)limited by different nutrients.

Plant and Soil, v.400, n.1, p.231-243, 2016. DOI: http://doi.org/10.1007/s11104-015-2725-9

MACHADO, S. L. M.; SALES, E. C. J.; REIS, S. T.; MESQUITA, V. G.; CARVALHO, Z. G.; MONÇÃO, F. P.; GOMES, E. A. S.; QUEIROZ, D. S.; LIMA, A. C. R.. Forage accumulation, tillering and bromatological characteristics of Brachiaria grass under nitrogen fertilization. Científica, v.45, n.2, p.197-203, 2017. DOI: http://doi.org/10.15361/1984-5529.2017v45n2p197$\underline{203}$.

MALAVOLTA, E.; VITTI, G. C.; OLIVEIRA, S. A.. Avaliação do estado nutricional das plantas: princípios e aplicações. Piracicaba: Potafos, 1997.

MIRANDA, K. R.; JUNIOR, D.; BATISTA, J. C.; MELLO, A. C. L.; SILVA, M. C.; SANTOS, M. V. F; SANTOS, D. C.. Forage production and mineral composition of cactus intercropped with legumes and fertilized with different sources of manure. Ciência Rural, v.49, n.1, 2019. Dol: http://doi.org/10.1590/0103-8478cr20180324

MYERS, N.; MITTERMEIER, R. A.; MITTERMEIER, C. G.; FONSECA, G. A. B.; KENT, J.. Biodiversity hotspots for conservation priorities. Nature, v.403, p.853-858, 2000. DOI: http://doi.org/10.1038/35002501

PIVELLO, V. R.; CARVALHO, V. M. C.; LOPES, P. F.; PECCININI, A. A.; ROSSO, S.. Abundance and distribution of native and alien grasses in a 'Cerrado' (Brazilian Savanna) biological reserve. Biotropica, v.31, n.1, p.71-82, 1999. DOI: http://doi.org/10.1111/j.1744-7429.1999.tb00117.x

R CORE TEAM. R: A language and environment for statistical computing. 2013.

RAIJ, B.; ANDRADE, J. C.; CANTARELLA, H.; QUAGGIO, J. A. Análise química para avaliação da fertilidade de solos tropicais. Campinas: IAC, 2001

SITTERS, J.; MAECHLER, M.; EDWARDS, P. J.; SUTER, W.; VENTERINK, H. O.. Interactions between C: N: P stoichiometry and soil macrofauna control dung decomposition of savanna herbivores. Functional Ecology, v.28, n.3, p.776-786, 2014. DOI: http://doi.org/10.1111/1365-2435.12213

SITTERS, J.; VENTERINK, H. O.. A stoichiometric perspective of the effect of herbivore dung on ecosystem functioning. Ecology and Evolution, v.8, n.2, p.1043-1046, 2018. DOI: http://doi.org/10.1002/ece3.3666

TEIXEIRA, D. S.; REZENDE, A. A.; LANNES L. S.. Response of vegetation and soil chemistry to sheep dung addition in a degraded Cerrado area. Revista Brasileira de Engenharia Agrícola e Ambiental, v.23, p.47-52, 2019. DOI: http://doi.org/10.1590/1807-1929/agriambi.v23n1p47-52

TEUTSCHEROVA, N.; VAZQUEZ, E.; AREVALO, A.; PULLEMAN, M.; RAO, I.; ARANGO, J.. Differences in arbuscular mycorrhizal colonization and $P$ acquisition between genotypes of the tropical Brachiaria grasses: is there a relation with BNI activity?. Biology and Fertility of Soils, v.55, n.4, p.325-337, 2019. DOI: http://doi.org/10.1007/s00374-019-01353-y

VALDÉS-CORRECHER, E.; SITTERS, J.; WASSEN, M.; BRION, N.; VENTERINK, H. O.. Herbivore dung quality affects plant community diversity. Scientific Reports, v.9, n.1, p.5675, 2019. DOI: http://doi.org/10.1038/s41598-019-42249-z

VENTERINK, H. O.; GÜSEWELL, S.. Competitive interactions between two meadow grasses under nitrogen and phosphorus limitation. Functional Ecology, v.24, n.4, p.877886. DOI: http://doi.org/10.1111/j.1365-2435.2010.01692.x

VENTERINK, H. O.. Does phosphorus limitation promote species-rich plant communities?. Plant and Soil, v.345, p.1-9, 2011a. DOI: http://doi.org/10.1007/s11104-011-0796-9

VENTERINK, H. O.. Legumes have a higher root phosphatase activity than other forbs, particularly under low inorganic $P$ and N supply. Plant and Soil, v.347, p.137-146, 2011b. DOI: http://doi.org/10.1007/s11104-011-0834-7

VAN DER WAAL, C.; KOOL, A.; MEIJER, S. S.; KOHI, E.; HEITKÖNIG, I. M. A.; DE BOER, W. F.; LANGEVELDE, F.; GRANT, R. C.; PEEL, M. J.; SLOTOW, R.; DE KNEGT, H. J.; PRINS, H. H.; DE KROON, H.. Large herbivores may alter vegetation structure of semi-arid savannas through soil nutrient mediation. Oecologia, v.165. n.4, p.1095-1107, 2011. DOI: http://doi.org/10.1007/s00442-010-1899-3

A CBPC - Companhia Brasileira de Produção Científica (CNPJ: 11.221.422/0001-03) detém os direitos materiais desta publicação. Os direitos referem-se à publicação do trabalho em qualquer parte do mundo, incluindo os direitos às renovações, expansões e disseminações da contribuição, bem como outros direitos subsidiários. Todos os trabalhos publicados eletronicamente poderão posteriormente ser publicados em coletâneas impressas sob coordenação da Sustenere Publishing, da Companhia Brasileira de Produção Científica e seus parceiros autorizados. Os (as) autores (as) preservam os direitos autorais, mas não têm permissão para a publicação da contribuição em outro meio, impresso ou digital, em português ou em tradução. 